\title{
Debt restructuring in the "new" Italian Insolvency Law
}

\section{Introduction}

The present contribution addresses the issue of debt restructuring in Italian Insolvency Law following its Reforms ${ }^{1}$ introduced by Legislative Decree n. 5/2006 and by Legislative Decree n. 169/20072.

Besides general bankruptcy (fallimento), the "new" legal framework provides for the "Reorganisation plan" (according to Art. 67, $\S 3$, lett. d.), Italian Insolvency Act), the out of court settlements

1 S. Sanzo, A. Bianchi, Manuale delle procedure concorsuali-Disciplina del fallimento, del concordato preventivo, della liquidazione coatta amministrativa - Aspetti fiscali e nuovi istituti per la crisi d'impresa, Milano 2008; S. Apice, S. Mancinelli, Diritto fallimentare - Normativa ed adempimenti, Torino 2008; G. Cassano, Il diritto fallimentare riformato - Schemi di confronto con il correttivo e formulario, Torino 2008; L. Farenga, La riforma del diritto fallimentare in Italia: una nuova visione del mercato, in Rivista del Diritto commerciale (Riv. dir. comm.), 2008, I, 251; A. Castagnola, keyword "Procedure concorsuali - Diritto fallimentare", in Il diritto-Encicl. giur., Milano 2007, vol. XI, 570; M.R. Grossi, keyword «Procedure concorsuali-Concordato fallimentare", in Il diritto-Encicl. giur., Milano 2007, vol. XI, 752; G. Schiano di Pepe (ed.), Il diritto fallimentare riformato - Commento sistematico, Padova 2007, S. Bonfatti, P.F. Censoni, Manuale di diritto fallimentare, II ed., Padova 2007; C. Cecchella, Il diritto fallimentare riformato, aggiornato al d.leg. 12 settembre 2007 n. 169, Milano 2007; L. Guglielmucci, Diritto fallimentare La nuova disciplina delle procedure concorsuali giudiziali, II ed. aggiornata con il decreto correttivo del 7 settembre 2007, Torino 2007.

2 Prior to the Reforms, Insolvency procedures were regulated by the Royal Law Decree of 16 March 1942, n. 267. 
with creditors, voluntary arrangements (concordato preventivo), the composition plan with creditors (concordato fallimentare) and the administrative liquidation (liquidazione coatta amministrativa).

Not surprisingly, the Reforms had a strong impact on the main players involved in insolvency proceedings ${ }^{3}$, i.e. the insolvency court, the insolvency judge (giudice delegato), the official receiver (curatore fallimentare) ${ }^{4}$ and the members of the creditors' committee (comitato dei creditori).

In order to better understand the extent and the implications of the recent Reforms in Italian Insolvency Law, a brief outline of the Equality and Priority of creditors principle and the relevant provisions ruling for "claw back" actions seems appropriate.

\section{Equality and Priority of creditors}

The leading principle of Italian Insolvency Law is the so-called par condicio creditorum, which means that all creditors have an equal right to payment and that the proceeds of the debtor's estate shall be distributed in proportion to the size of creditor's claims.

3 Specifically, jurisdiction of the insolvency court has been extended to any claim consequent to the insolvency order, as well as on any application made against the insolvency judge decisions. Management and decision powers have been shifted in favour of the official receiver and members of the creditors' committee, who shall supervise the official receiver's course of action during administration and liquidation of the insolvent estate. Its components may be held liable for their action according to the company law regulations concerning supervisors (sindaci) in limited liability companies.

4 According to Italian Insolvency Law, the appointment of "official receivers" shall be made not only among solicitors and chartered accountants - as before - but also partnerships among solicitors or accountants or former directors or general managers of limited liability companies holding specific capabilities in administrating, directing or controlling companies. The official receiver may appoint solicitors, and shall prepare a liquidation schedule. According to Italian Regulations, official receivers act both as a receiver and as a liquidator. 
However, there are two groups of creditors that enjoy preferential treatment, to whom the equality principle does not apply: creditors who hold a security interest (creditori ipotecari e pignoratizi - so called "secured creditors") and preferred creditors (creditori privilegiati).

According to Italian Law, the principal categories of secured creditors are:

- creditors who hold a mortgage on immovables (i.e. real property) of the debtor; and

- creditors who hold a pledge on movable assets of the debtor or on claims of the debtor against third parties.

A "preferred creditor" (creditore privilegiati in senso stretto) is a creditor whose claim is given statutory preferential treatment over other creditors ${ }^{5}$. No priority lien may be created contractually. Such liens may apply to all of the debtor's property or solely to specific property.

The Italian Civil Code contains very detailed rules (Art. $2745 \mathrm{ff}$. Codice civile [Italian Civil Code]) regulating priority conflicts between secured and preferred creditors.

As a general principle, creditors holding a security interest are paid to the exclusion of all other creditors, including secured creditors having a lower rank (e.g. first degree mortgage over second degree mortgage).

Unsecured creditors (creditori chirografari) have no preference and will therefore be paid only if any proceeds of the estate remain after all other creditors have received payment ${ }^{6}$. Accordingly, unsecured

5 The preferences of the tax and social security administrations are, together with the employees salaries, among the highest in the rank.

6 The order of the distribution of assets as regards general claims - that is assets which are not secured by special privileges, charges, or other forms of security - is as follows:

1. The costs of bankruptcy proceedings, which have priority even over secured claims such as mortgages and pledges;

2. Employment compensation, including, without limitation, termination benefits;

3. Claims of independent professional contractors who performed services for the insolvent company/individual entrepreneur during 
creditors will share equally in the estate, in proportion to the size of their claims ${ }^{7}$.

Therefore the equality principle only applies to those creditors who have an unsecured claim and are not preferred creditors. They share pro rata in the amount available to them.

the twelve month period prior to the insolvency order; commissions due within the previous twelve months pursuant to agency agreements and compensation for the termination of an agency;

4. Taxes on real property;

5. Claims of farmers;

6. Claims of suppliers of production plants and equipment, and claims of banks which financed the purchase thereof;

7. The debtor's expenses for food, clothing, lodgings, medical treatment or funeral arrangements, incurred within a period of six months prior to the insolvency order, as well as the expenses relating to the support of the debtor's family within the previous three months.

8. Income taxes (subject to certain limitations);

9. Local taxes, social security payments and insurance premiums.

Any sum due in a foreign currency will by converted into EURO as of the date of the insolvency order according to the rate of exchange then in force.

Other debts and counterclaims are off set at the same date.

7 Absent statutory priorities, no creditor may be paid a higher percentage of their claims than other creditors. In the case of insolvency, preferential payments may lead to criminal and/or civil liability for the debtor or their Directors and may also be set-aside as a consequence of "claw back" actions initiated by other creditors. If an Insolvency Proceeding is pending (for instance, a pre-insolvency composition plan, a Bankruptcy, an Extraordinary Administration Proceedings), preferential treatment granted to certain creditors to the detriment of other creditors could result in a criminal offence (according to Art. 216 Italian Insolvency Act), provided that the debtor's main intention was to further the preferred creditors' interests. Moreover, Directors may be held liable for preferential payments to one or more of the company's creditors for violating "their duties concerning preservation of the company assets" under Art. 2394 Codice civile (Italian Civil Code). 


\section{“Claw back" Actions in Italian Insolvency Law}

Insolvency regulations entitle official receivers to apply to the court in order to have set aside a wide range of transactions entered into before the opening of insolvency proceedings, i.e. to bring a "claw back" action (azione revocatoria).

Recent Reforms ${ }^{8}$ amended the provisions allowing an official receiver to "claw back" a wide range of transactions entered into in the period leading up to insolvency. The aim of these changes has been to balance the needs of creditors to an adequate protection against certain "suspect" transactions in the run up to insolvency with the interests of debtors in financial distress to extricate themselves (for example by selling a business or subsidiary or refinancing their debt).

Specifically, according to Art. 67, § 1, Italian Insolvency Act, the court appointed official receiver is entitled to start legal proceedings (by filing a "claw back" action) in order to have the following transactions set aside:

- transactions for no consideration ("gratuitous") entered into by the insolvent company/individual entrepreneur ${ }^{9}$ in the year before the insolvency order;

- any transaction at an undervalue carried out by the insolvent company/individual entrepreneur in the year before the insolvency order. A transaction is assumed to be "undervalue" when the actual value of the consideration paid to the debtor is less than one quarter in comparison to the value of the counterparty's consideration;

8 The 2005 Reform applies to winding up proceedings opened after 17 March 2005.

9 According to Art. 1 Italian Insolvency Act, the new regulation is applicable to both companies and individual entrepreneurs providing:

- the overall value of the business assets and investments at stake exceed the threshold of $€ 300$ 000,00;

- the average gross annual turnover during the previous three fiscal years is higher than $€ 200000,00$;

- the debtor is deemed to be "insolvent», i.e. unable to pay its debts on a regular basis by way of a common means of payment. 
- any discharge of due and payable obligations performed in the year before the insolvency order, made by means other than money or by uncommon means of payment (such as, for example, the transfer of goods to a creditor to discharge a payment obligation);

- any security (pledge and mortgage) granted by the insolvent company/individual entrepreneur in the year before the insolvency order to secure pre-existing debts not yet due at the time the relevant security was granted;

- any security (pledge and mortgage) granted by the insolvent company/individual entrepreneur in the six months prior to the insolvency order to secure pre-existing debts that were due and payable at the time the relevant security was granted.

With reference to the above-mentioned transactions, the official receiver does not have to demonstrate any intention by the distressed company/individual entrepreneur to defraud or cause a prejudice to the creditors, or that the beneficiary was aware of the debtor's "state of crisis" at the time of the transaction. The beneficiary can resist the "claw back" action by rebutting the burden of proof, i.e. by proving that - at the time when the transaction under scrutiny took place - they were not aware of the debtor's "state of crisis", i.e. that such party was no longer able to regularly perform its obligations at the time in which the relevant transaction was performed.

In order to have the following transactions set aside, the official receiver has to prove that the beneficiary was aware of the debtor's "state of crisis" at the time when the transaction took place, provided it occurred within six months of the bankruptcy order:

- any repayment of debt already due and enforceable made through normal means;

- any pledge or mortgage granted by the debtor as security for debts arising simultaneously with the grant of the security;

- any other transaction for consideration.

Finally, according to Art. 67, § 3, Italian Insolvency Act, the following transactions are unchallengeable by the official receiver ${ }^{10}$ :

10 See V. Giorgi, Le esenzioni della revocatoria fallimentare per favorire la normale prosecuzione dell'impresa (art. 67, 3ํomma, lett. a) ed f), legge 
- payments for goods and services made in the debtor's ordinary course of business and in accordance with customary terms and conditions;

- banking remittances, except for those that significantly increased the company's indebtedness towards the bank;

- sale of land to be used by the purchaser for their or their close relative's living purposes;

- transactions, payments and guarantees over the debtor's assets carried out or granted:

a) according to a Reorganisation plan (see below § 4) agreed upon with creditors, aimed at reducing the company's liabilities and rebalancing its financial position, "validated" by a favourable opinion of an independent expert ${ }^{11}$;

b) pursuant to a voluntary Restructuring arrangement (see below $\S 5$ ) or a debt restructuring plan ${ }^{12}$;

- any payment made to the employees and consultants;

- any payment of receivables due to obtain services required for the admission to the voluntary arrangement with creditors.

\section{The "Reorganisation plan"*}

According to Art. 67, § 3, lett. d.), Italian Insolvency Act, a distressed company/individual entrepreneur can draw up a Reorganisation plan indicating how it/they intends to sort out of its/

fallimentare), in Dir. fall., 2008, I, 392; L. Salamone, L'esenzione dell'azione revocatoria fallimentare dei "pagamenti di beni e servizi effettuati nell'esercizio dell'attività d'impresa nei termini d'uso" (art. 67, 3o comma, lett. a), l. fall.), in Banca, borsa e titoli di credito (BBTC), 2008, I, 43; G. Tarzia, L'ambito di applicazione delle esenzioni nel nuovo art. 67 l. fall., in Fall., 2008, 637; A. Vincenti, In tema di revocatoria delle rimesse in conto corrente: qualche riflessione sul testo rinnovato dell'art. 67 l. fall, in BBTC, 2008, II, 678; P. Piscitello, Piani di risanamento e posizione delle banche, in BBTC, 2007, I, 538; G.B. Nardecchia, Il periodo sospetto nella nuova disciplina della revocatoria fallimentare, in Fall., 2008, 1245.

11 See below $\S 4$.

12 See below $\S 5$ and $\S 6$.

* See Art. 67, § 3, lett. d.), Italian Insolvency Act. 
/their current financial difficulties and to comply with its/their ongoing payment obligations.

Creditors are under no obligation to accept the Reorganisation plan submitted by the distressed company. Should (some) creditors refuse approval, the distressed company/individual entrepreneur may ask an independent expert to "validate" the Reorganisation plan, provided that - according to their opinion - the plan shows that the distressed company/individual entrepreneur may overcome its financial difficulties, assuming full payment of the creditors that refuse to accept the plan.

The most important substantial implication of the "validation" by an independent expert is that all actions taken in order to implement the plan are not subject to "claw back" provisions.

Therefore, the "validation" of the Reorganisation plan according to Art. 67 Italian Insolvency Act facilitates its implementation by the distressed company/individual entrepreneur, given that- in the absence of the "validation" and regardless of Art. 67, § 1, Italian Insolvency Act - as soon as rumours of financial difficulties spread third persons would probably hesitate before entering into contractual relations with the distressed company/individual entrepreneur for fear of being subject to "claw back" provisions, should the company/ /individual entrepreneur subsequently be adjudicated bankrupt.

\section{Out of court settlement with creditors ("Restructuring arrangements")*}

Should a Reorganisation plan not be approved by all creditors, the distressed company/individual entrepreneur can resort to the procedure ruled by Art. 182-bis Italian Insolvency Act, providing for a so-called Restructuring arrangement (accordo di ristrutturazione) ${ }^{13}$.

* See Art. 182-bis Italian Insolvency Act (as distinct from a Reorganisation plan).

$13 \mathrm{~S}$. Ambrosini, Il concordato preventivo e gli accordi di ristrutturazione dei debiti, Padova 2008; L. De Angelis, Gli accordi di ristrutturazione e le banche, in Società, 2008, 1462; G. Minutoli, Autonomia privata e ruolo del professionista negli accordi di ristrutturazione dei debiti, in Fallimento \& crisi 
The proposed Restructuring arrangement needs to be submitted together with an expert's report assessing its feasibility and confirming the debtor's ability to pay the non-consenting creditors.

In order to have a Restructuring arrangement according to Art. 182-bis Italian Insolvency Act, the following requirements have to be met:

- the distressed company has reached a debt restructuring agreement with creditors representing at least $60 \%$ of its debts ${ }^{14}$;

- the distressed company has filed an application with the court for the "certification" (omologa) of the Restructuring arrangement, together with a statement by an independent expert confirming the feasibility of the Restructuring arrangement, with particular reference to the distressed company's ability to ensure the regular payment of creditors refusing to approve the Restructuring arrangement;

- the Restructuring arrangement has been registered with the competent Companies' Registry.

The certification of the Restructuring arrangement by the competent Court exempts any action taken or payment made by the distressed company/individual entrepreneur from the "claw back" actions provided for under Italian Insolvency Law ${ }^{15}$.

Furthermore, it leads to the application of a 60-day moratorium on any interim relief or enforcement action over the assets of the distressed company in relation to pre-existing debts.

impresa, 2008, 447; G.B. Nardecchia, Gli accordi di ristrutturazione dei debiti ed il procedimento per la dichiarazione di fallimento, in Fall., 2008, 703; G. Verna, I nuovi accordi di ristrutturazione (art. 182 bis l.fall.), in Dir. fall., 2007, I, 942; V. Bellucci, Gli accordi di ristrutturazione dei debiti (prima e dopo il decreto correttivo n. 169 del 12 settembre 2007), in Rivista del Diritto commerciale (Riv. dir. comm.), 2008, I, 483; G. Presti, keyword «Procedure concorsuali - Accordi di ristrutturazione dei debiti, in Il diritto-Encicl. giur., Milano 2007, vol. XII, 45; F. Innocenti, Gli accordi di ristrutturazione dei debiti nel quadro dell'intervento correttivo del 2007: una possibile soluzione alla crisi d'impresa, in Diritto fallimentare (Dir. fall.), 2007, I, 917.

14 The delayed payment of non-consenting creditors is not admissible: see App. (App. = Court of Appeal) of Trieste, 4 Sept. 2007, in Dir. fall., 2008, II, 297, with a commentary by Manente.

15 See above $\S 3$. 
It should be noted that no cram down applies to third party creditors who have not reached a restructuring agreement with the distressed debtor or who have not entered into the Restructuring arrangement.

\section{The pre-insolvency composition plan with creditors (concordato preventivo)*}

Judicial composition with creditors is a court ordered procedure the purpose of which is to avoid insolvency ${ }^{16}$. It aims at reorganising the activity of the insolvent company/individual entrepreneur through an agreement between the debtor and its creditors.

* See Art. 160 ff. Italian Insolvency Act. L. Abete, Il ruolo del giudice ed il principio maggioritario nel novello concordato preventivo: brevi note, in Fall., 2008, 253; S. Ambrosini, Il concordato preventivo e gli accordi di ristrutturazione dei debiti, Padova 2008; M. Arato, La domanda di concordato preventivo dopo il d.leg. 12 settembre 2007 n. 169, in Dir. fall., 2008, I, 53; G. Bersani, Pagamento dei crediti privilegiati speciali nel concordato preventivo, in Fallimento \& crisi impresa, 2008, 733; G. Brescia, Relazione dell'esperto per l'ammissione al concordato preventivo, in Fallimento \& crisi impresa, 2008, 361; M. Galardo, Eccezione di dolo, concordato preventivo e par condicio creditorum, in Dir. fall., 2008, II, 274; G. Fauceglia, Paternalismo giudiziario ed esigenza di tutela dei creditori nella disciplina del concordato preventivo, in Giurisprudenza italiana (Giur. it.), 2008, 119; P. Filippi, Omologazione del concordato preventivo: questioni vecchie e nuove, in Giurisprudenza di merito, 2007, 3219.

16 The "autonomy" between Restructuring arrangements and pre-composition plans with creditors has been stated by: Trib. (= First instance court) Trib. of Milan, 23 Jan. 2007, in Fallimento (Fall.), 2007, 701, with a commentary by Dimundo; in Diritto e pratica fallimentare (DPF), 2007, n. 5, 57, with a commentary by Gaeta; in Giur. it., 2007, 1692; Trib. of Milan, 11 Jan. 2007, in Dir. fall., 2008, II, 136, with a commentary by Proietti; Trib. of Udine, 22 June 2007, in Fall., 2008, 701, with a commentary by Nardecchia; Trib. of Brescia, 22 Feb. 2006, in Foro italiano (Foro. it.)., 2006, I, 2563, with a commentary by M. Fabiani; in Fall., 2006, 669 , n. with a commentary by Nardecchia. 
Specifically, any company/individual entrepreneur who faces a "state of crisis" may apply to the insolvency court in order to access such arrangements.

According to Italian Insolvency Law, any kind of restructuring of the liabilities and payment of the creditors, also by means of transfer of goods and other extraordinary transactions (for instance, the assignment of assets or the transfer of shares or financial instruments to creditors as a means to satisfy their claims), is admitted. The debtor may also propose partial payment of secured and preferred creditors.

Furthermore, the creditors can be sorted into classes, according to their position and uniform economic interests. If this occurs, only different classes of creditors can be given different treatment (i.e. par condicio creditorum will have to be observed between creditors of the same class).

The insolvency court can start the procedure and i.) appoint a delegate judge and a judicial commissary (commissario giudiziale); ii.) call a creditors' meeting within 30 days (even though this is not a mandatory term).

At the creditors' meeting, the judicial commissary illustrates the proposal made by the debtor in order to pay the creditors.

The pre-insolvency composition plan must be approved by creditors representing:

- the majority of credits admitted to vote; and

- if the creditors are divided into different classes (according to their position and uniform economic interests), the majority of classes ${ }^{17}$.

Once approved, the composition plan is binding on all creditors.

Therefore, the pre-insolvency composition plan entails the possibility of a cram down, both with reference to dissenting (minority)

17 See P. Farina, Calcolo delle maggioranze e tutela dei creditori nel concordato preventivo, in Dir. fall., 2008, II, 325; O. De Cicco, Le classi di creditori nel concordato preventivo-Appunti sulla par condicio creditorum, Napoli 2007. 
creditors and/or to (majority) creditors belonging to a class refusing the plan, so long as the majority of classes approved it.

It is discussed whether the power granted to the insolvency court is limited to ascertaining solely that majority was reached, or whether it has stronger powers to investigate whether the proposal is convenient for the creditors.

Secured creditors who will be fully repaid under the composition plan are not admitted to vote, unless they waive in all or in part their priority rights. Should the pre-insolvency composition plan provide solely for the partial payment of secured creditors, these will be treated as unsecured creditors in relation to the unpaid portion of their claims (which means that, in relation to such portion, they will be entitled to vote).

The effective implementation of a pre-insolvency composition plan often requires years, as it often involves litigation flowing from the right attributed to dissenting or non-voting creditors to challenge the composition plan and, even after approval, to challenge the filing of concurrent credits (see Art. $174 \mathrm{ff}$. Italian Insolvency Act).

\section{Extraordinary Administration Proceedings}

A further insolvency procedure, the "extraordinary administration of large companies" 18 (provided for by Legislative Decree $\mathrm{n}$. 270/1999 - the so called "Prodi-bis Proceedings"), may be requested by distressed companies which:

18 N. Nisivoccia, Accordi di ristrutturazione e liquidazione coatta amministrativa: le novità, in DPF, 2008, n. 5, 6; S. Allodi/S. Castenetti, Novità sull'amministrazione straordinaria delle grandi imprese in crisi, in Diritto e pratica delle società (DPS), 2008, n. 20, 20; F. Tommaso, La riforma del concordato nella liquidazione coatta amministrativa e nell'amministrazione straordinaria ad opera del decreto correttivo, in Fall., 2008, 110; Id., Il concordato nella liquidazione coatta amministrativa dopo le riforme della legge fallimentare e la garanzia patrimoniale ex art. 2740 c.c., in Giurisprudenza commerciale (Giur. comm.), 2007, II, 1182; G. Battaglia, keyword "Procedure concorsuali - Liquidazione coatta amministrativa", in Il diritto-Encicl. giur., 
- have employed at least 200 employees during the previous year;

- have debts amounting to at least two thirds of their total assets and turnover of the previous fiscal year;

- have the perspective of being rescued through either:

a) disposal of assets plan not exceeding one year,

b) or a restructuring plan not exceeding two years.

A distinction has to be drawn: if the applicable proceeding is based on an asset disposal plan, creditors will be repaid out of the proceeds of the disposals; if the extraordinary administration provides for a restructuring plan, it may actually contemplate a reduction of the amount of the guarantee.

A different type of procedure - even though referred to as extraordinary administration for large companies - has been introduced with Decree n. 347/2003 (the so called "Decreto Marzano Proceedings"), which applies to companies having employed at least 500 employees in the last year before filing for bankruptcy.

Finally, specific rules were introduced with Law Decree n. $134 / 2008$ for large companies operating in the field of essential public services with the declared purpose of guaranteeing the continuity of the supply of such services ${ }^{19}$.

Milano 2007, vol. XII, 68; P.D. Beltrami, Conversione del fallimento nella procedura di amministrazione straordinaria "speciale" (decreto Marzano), in Giur. comm., 2008, II, 1067 ss.; A. Casotti, M.R. Gheido, Disposizioni urgenti in materia di ristrutturazione di grandi imprese in crisi (commento al d.l. 28 agosto 2008 n. 134), in Guida al diritto, 2008, n. 38, 32; A. Daccò, keyword "Procedure concorsuali - Legge Marzano", in Il diritto-Encicl. giur., Milano 2007, vol. XII, 94.

For the difference between extraordinary administration procedures for large companies in a state of crisis and Restructuring arrangements, see N. Nisivoccia, Accordi di ristrutturazione e liquidazione coatta amministrativa: le novità, in $D P F, 2008$, n. 5, 6.

19 The Decree was actually conceived as an ad hoc measure to rescue Alitalia. It is not a new approach in Italy: the "Marzano Decree" was originally approved to tackle the Parmalat collapse and was subsequently amended to allow the Volare Group to access this special procedure: see G. Lo Cascio, Insolvenza Alitalia: nuova versione dell'amministrazione straordinaria (commento al d.l. 28 agosto 2008 n. 134), in Fall., 2008, 1113 ; 
The main new provisions are as follows:

- the government has the power to give the commissioner orders when the procedure is initiated and to set guidelines for the procedure; this provision has been strongly criticized, since it potentially puts significant political pressure on the supposedly independent commissioner;

- the aim of the procedure is no longer to restructure the insolvent company, but simply to sell its assets ${ }^{20}$. Thus, the commissioner may now immediately negotiate and conclude the sale of a good company to the potential purchasers (the law previously required the commissioner first to attempt to restructure the company by filing a restructuring plan);

- the commissioner is entitled to initiate and conduct private negotiations with potential purchasers, rather than holding a public auction;

- deals which might be deemed to be concentrations under Antitrust law are no longer subject to the prior authorization of the Antitrust Authority. The Authority may impose measures only if they are necessary to prevent unjustified and onerous contractual conditions from affecting consumers.

\section{Concluding remarks}

The Insolvency Law Reforms aim at preserving the goodwill of the company/individual entrepreneur, as long as that result is (considered to be) feasible and thus coincides with the interest of the creditors.

Id., Gruppo Alitalia: conversione del decreto legge sull'insolvenza (commento al d.l. 28 agosto 2008 n. 134), in Fall., 2008, 1365; P. Manganelli, Da Parmalat ad Alitalia: strumenti di gestione della crisi d'impresa, in DPS, 2008, n. 23, 24; G. Penna, Decreto "salva Alitalia" e questioni di responsabilità degli organi societari, in DPS, 2008, n. 18, 6.

20 Thus Law Decree 134/2008 practically eliminates the main function of the extraordinary administration procedure, which used to be the restructuring a corporation that has been declared insolvent. 
In order to preserve the company/individual entrepreneur as a going concern, the Reforms grant the debtor facing a "state of crisis" the right to submit specific debt restructuring plans to creditors, which - depending amongst others on the percentage of creditors approving them and on the specific type of restructuring plan - will also be binding for the dissenting creditors.

At them same time the Reforms aim at making the liquidation procedure of the debtor's assets more simple and efficient, should a rescue plan of the business not appear to be reasonable: depending on the interest of the creditors, the official receiver is entitled either to sell the company's assets in a manner they determine to be appropriate, according to a liquidation programme to be formed by the official receiver themselves (which is to be approved by the insolvency judge, subject to prior consent by the creditors' committee) or to temporarily carry on the business, after having been granted authorization by the insolvency judge, with the previous favourable opinion of the creditor's committee. 